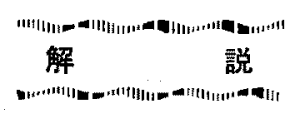

\title{
回収体の軌道と誘導についで
}

\author{
田中俊 輔**.池，由 \\ Key words : Re-entry trajectory; Re-entry guidance; Lifting body; \\ winged body; closed form re-entry guidance
}

茂**

1.はじめに

スペース・シャトルの初飛行が成功し，無事に地球 亿帰睘した．続いて次々之試験飛行が行われている. これらの成功により人類の宇宙空間における活動籍用 は飛躍的に增大し，さまざまの活動が行われるである う. わが国でも宇宙空間を利用した実験が行われてい るが，今後われわれの活動もより多樣になっていくと 思われる.これらの活動のなかで回収の問題も重要な あのの一つになるであろう. 現在, カプセル型回収体 を用いた生物実験構想》や小型有翼回収機を用いた有 人による宇宙開発構想”功発表されている，回収シる テム技術は多岐の分野にわたる，各分野に扔ける詳細 な检討は別の機会にゆずり，とこでは回収体の軌道、 誘導の面から, 軌道の特徽, お上び種々の誘導方式上 その計算例を紹介する。

\section{2. 回収体の誘葶システム}

人工衛星や有人，無人の飛行体を地球の周回轨道ま たは月，惑星を回る軌道に投入するには莫大なエネル ギーを必要とする．この必要なエネルギーは，口ケッ 卜に積載された化学燃料を短時間のうちに燃焼させて 得ている.いったん軌道侸乗った飛行体はエネルギー 保存の法則に往って長時間，周回を続ける。. ての飛行 体の一部または住部（以後回取体とよぶ）を地上汇回 収したいという要求に対して，回取体のすつ大きな工 ネルギーをいか炕消散させて，安全に地上の目標点に 誘導するかが，回収体の誘導の目的である．回叔体に 加わる力性空気力と重力であり，誘導は空気力を利用 して行う．ての場合，回収体はロケットに比へてはる が複雑な運動を行い，軌道のコントロールを誤まる

\footnotetext{
*䀡和 57 年 6 月 14 日 原稿受理；Trajectory and Guidance of Re-entry Vehicles

** 宇宙開発事粟団筑波宇宙センター Shunsuke TANAKA and Shigeru IKEDA
}

と，空気抵抗によって機体が破墒したり，あるいは空 気力によって発生した熱によって機体汃消滅するとと さえある。

回収体の誘導は回収体の形状，重量，招上び機体の 設計強度, 耐熱限界, 基本的な軌道等, 全体のシステ ムと密接に関連しあっている。:誘導システムとはとれ らを考慮した上での, 要求誘導精度を渶たす誘導航法 論理 (ソフトゥエア）とこれを実行する計算機，慣性 航法装置 (ハードウェア) をいう.

\section{3. 回収体の飛行 $(\boldsymbol{L} / \boldsymbol{D}:$ 一定 $)$}

回収体の轨道，誘導の問題を考える場合には，機体 は質点と考えて十分であり，初期の検討段階では地球 の自転の影響は無視する。地球をとりまく大気の密度 ( $\rho)$ は高度 $(h)$ の增加化伴。て指数関数的に隇少する ことが知られており，次のような近似式が上く用いら れる。

$$
\rho=\rho_{0} e^{-h / h} s, \rho_{0}, h_{s}: \text { 定数 }
$$

回收体汇加わる空気力には，速度ベクトルと逆方向

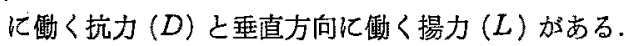
との空気力を表わす重要なパラメータとしては揚抗比 $(L / D)$ 之弾道係数 $\left(W / C_{\mathrm{D}} A, C_{\mathrm{D}}\right.$; 抵抗係数, $A$ : 基 準面穑， $W$ : 機体重量)である.とれらはいずれあ機 体形状，重量によって決まる。 また重力加速度は地球 中心から機体重心までの距離の 2 乗に反比例する球形 地球モデルや，重力加透度が一定とした平坦地球モデ ルが用いられる．回収体の運動を表加す座標系注，機 体重心炕原点をとり，地球中心之機体重心を結ぶ距離 ベクトル方向に一軸を，との距踓ベクトルに直交する 平面（局所水平面）内で，北方向，束方向に二軸をと った局所水平座標系，または同じく機体重心に原点を もち速度ベクトル方向に一軸，飛行面に垂直に一軸を とり，ての二軸と右手直交系をなす方向にもう一軸を 上った速度軸座標系が用いられる．とれらの座標系は 航空機の運動を表わすのによく用いられ，之くに速度 


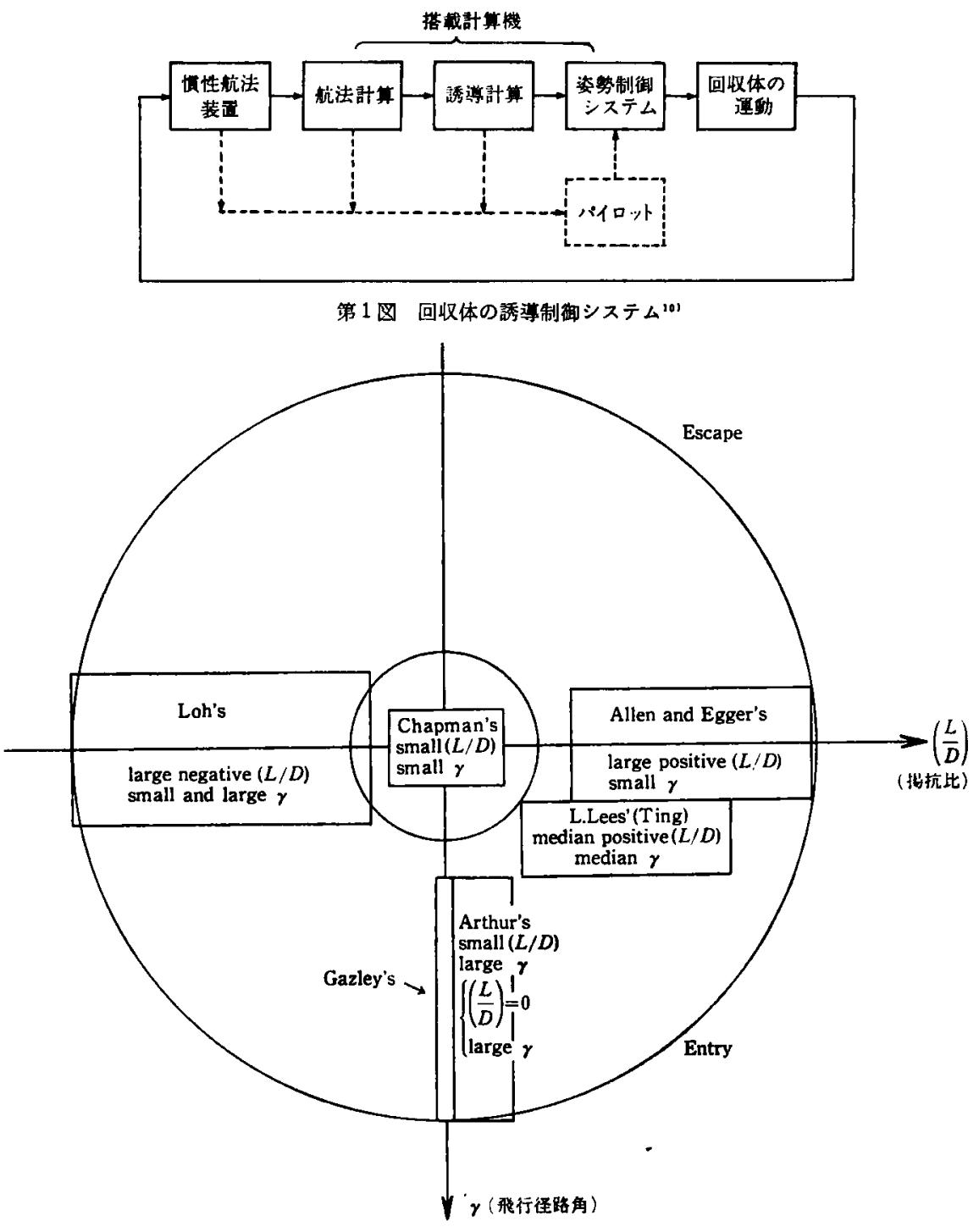

第2图回收休の運勘方程式の近似解析解

轴座標系では空気力の取扱いが非常に简単になる，回 収体の通動方程式は以上の仮定や近似式を用いても非 線形設分方程式となり，計算機を用いた数值計算に頼 らざるをえない，むし回収体の軌道か解析的に得られ れば回収体に加わる空力荷重や空力加熱等加容易に推 定でき，機体の初期設計には非常に有効である. 1950 年代後半より多くの研究者によって速度轴座標系を用 いた回収体の運動方程式を解析的に解く式みがなされ てきた。解析的に解が得られている籍围は，揚抗比 $(L / D)$ と飛行径路角 $(\gamma)$ で表わすと第 2 図で表わさ れる.これらのうち回収体の誘導の理解に役立つ結果 について简単に触れる. GAZLEY, ALLEN`) は揚抗比 $(L / D)$ が 0 で大気圈笑入時の初期飛行径路角 $\left(\gamma_{1}\right)$ か
大きい場合の解析解を㲩いた，揚抗比が 0 の飛行は弾 道飛行とよばれ，球形の形状を有するソ連のボスト一 クや，機軸（ロール軸）の回りに一定の角速度で回転 させて降下した米国のマーキュリー・カプセルの飛行 はこの弾道飛行である. GAZLEY, ALLEN の解析結果

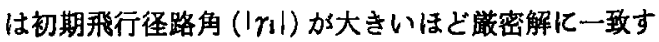
る. LEES $^{5}$ ）回収体の速度が，地球周回軌道速度 (約 $7,909 \mathrm{~m} / \mathrm{sec})$ 飞近い場合について解析解を得ている. 地球の回りを回る飛行体を回収する場合，大気圈の上 部では空気の影製は少なく，あまり減速されずての仮 定にあてはまるから，回収体の初期突入時の軌道はて の解析結果とよく一致する. ARTHUR ${ }^{6)}$ の解析は掦抗 比 $(L / D)$ 汃小さくて, 飛行径路角 $(\gamma)$ が初期飛行径 
路角 $\left(r_{i}\right)$ に近い場合について解を得ている. 米国のジ エミニ・カプセルでは揚抗比は 0.19, アポロ・カプセ

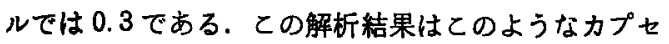
儿型の低揚抗比の初期軌道に適用できる．そして初期 飛行径路角 $\left(\left|\gamma_{\mathrm{i}}\right|\right)$ が大きいほど䈗密解化一致する。

次に ALLEN, EGGERS ${ }^{7}$ は揚力と遠心力との和が重 力と俆り合った飛行状態について解析を行った．との 場合, 飛行径路角の变化率 $(d \gamma / d t)$ はほとんど0であ る. この飛行は平衡滑空飛行とよばれ，回収体の軌道 や飛行可能領域を考虑する祭の基本となっている．ま た回収体の誘導論理にる利用され，シャトル・オービ ターの回収誘導にす取り入れられている。

最後に重要な解析の一つに CHAPMAN ${ }^{82}$ の解析があ ろ. ChaPMAN は局所水平座標を用いて回収体の運動 を表わし，揚抗比 $(L / D)$ 之飛行径路角 $(r)$ が小さい 場合について方程式を簡約化した。 これには大気密度 (o) と水平方向の速度 $(u)$ の皘化比例す万新しい変数 (Z関数とよばれている) を票入している.との $Z$ 関 数を用いると, 回収体の運動方程式は $Z$ の水平方向速 度 (u)に関する 2 階の常微分方程式として表わすてと ができる. この微分方程式を解いて， $Z$ および $Z$ の 変化事 $(d Z / d u)$ を求めると, 空力荷重, 空力加熱率, 飛行距離等が容易に得られる。 CHAPMAN の結果はこ れまでの例のような解析解ではないか，この微分方程 式を解いて得られる結果は軌道全体にわたって蕨密解 とよく一致する. 文献”でもこの方程式について詳細 な検討汃行われている. また CHAPMAN の微分方程式 は後に述へるように回収体の誘導論理の一つとして利 用できる。

\section{4. 回収体の冢行 $(\boldsymbol{L} / \boldsymbol{D}:$ 可変)}

回収体の揚抗比 $(L / D)$ を一定として地球周回軌道 より大気圈（高度約 $120 \mathrm{~km}$ ) に突入すると第 3 図江示 すように機体は減衰提動を行いながら降下し，最後に は，揚力之遠心力の和か重力之釣り合った平衡状態之 なって飛行する. この振動は phugoid 振動とよばれ， 大気圈突入時の飛行往路角 $\left(\gamma_{i}\right)$, 揚抗比 $(L / D)$ 加大 きくなるほど散しくなる．とのような振動は飛行瑔 境, 軌道のコントロールの面からは好ましくない，こ のため，揚抗比 $(L / D)$ を変化させて，軌道の減衰を 早めたり，過大な空力荷重，空力加熱をさりるよう， 回収体の飛行に一定の拘束を設けて飛行を行う方法か とられる. 拘束の例としては
(1) 一定抗力飛行
（2）一定飛行径路角飛行
（3）一定高度または一定高度变化率飛行
（4）一定空力加鶖率飛行
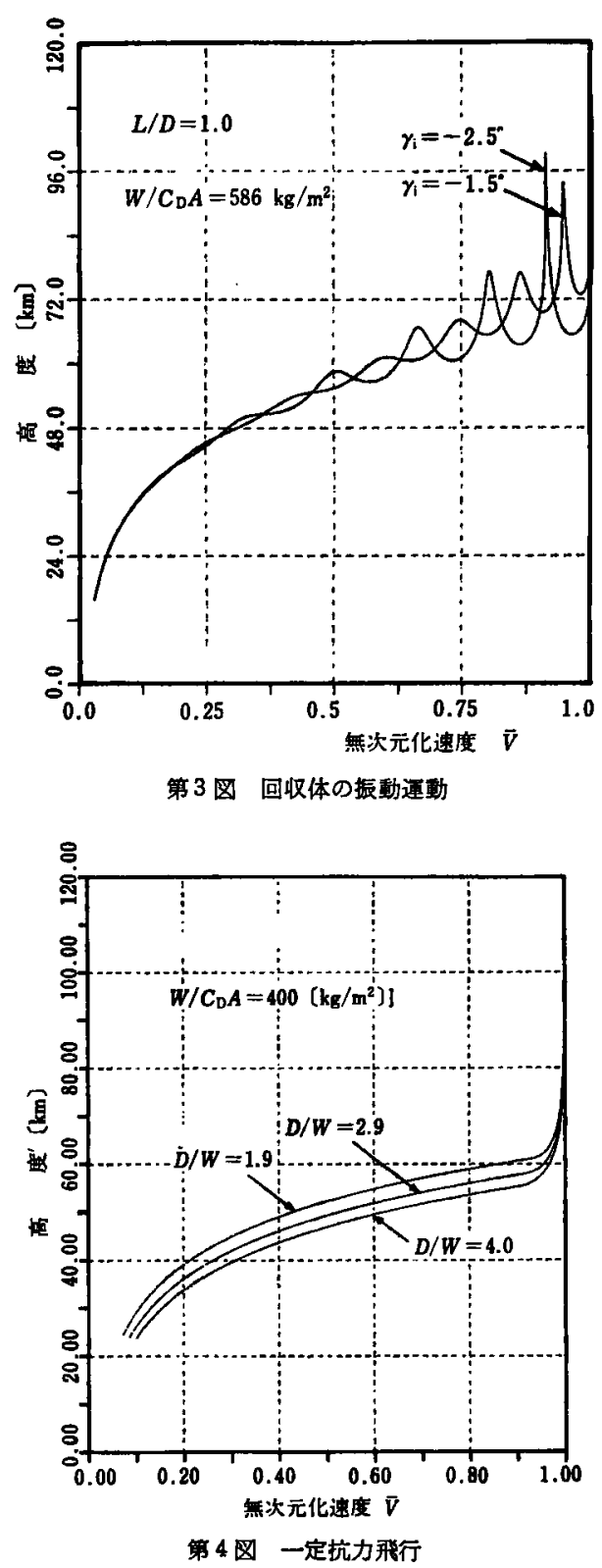

等がある. 回収体汃このようる拘束条件のもとに飛行 する場合には速度に対する回収体の高度, 飛行距離, 飛行径路角等の飛行状態量加解析的任容易に得られ, 回収体の誘導に利用される．とのいくつかについて説 明する。

4.1 一定抗力我行 (constant drag flight) 空気 抵抗による減速度は弾道係数 $\left(W / C_{\mathrm{D}} A\right)$ の逆数之動圧 $\rho V^{2} / 2 ， V:$ 機体速度) の積で与えられる. 弾道係数 か一一定の場合には，一定抗力飛行は動氏が一定の飛行 といいかえるとともできる．高度 $120 \mathrm{~km}$ より大気圈 に实入して，一定抗力飛行に移行した飛行プロファイ 
ルを第 4 図に示す，この図でV゙は機体速度 $(V)$ を地球 周回速度 ( $V \overline{g r 0} ， g$ : 重力加速度, $r_{0}$ : 地球半径) で無 次元化したものである. まだパラメータ $(D / W)$ は抗 力加速度 $(g$ 単位)である.

乙の飛行の初期突入部分は既述の LEES の解析結果 を用いている. この一定抗力飛行では飛行距離は速度 の 2 次式として，また飛行時間は速度の 1 次式として 得られる。

\section{2 一定飛行径路角飛行 (constant flight pass} angle Hight) 乙れは回収体が決められた飛行径路 角 $(r)$ で飛行するあので，乙の場合，回収体の飛行高 度 $(h)$ は，速度 $(V)$ の対数関数として得られる. 第 5 図は高度 $120 \mathrm{~km}$ 上り初期飛行径路角 $\left(\gamma_{i}\right)$ かs $-1.5^{\circ}$, $-2^{\circ} ，-3^{\circ}$ で大気圈に实入し，初期飛行径路角の $1 / 2$ になったところで，飛行径路角を固定し降下した例を 示す. との飛行の場合も, 空力荷重, 飛行距離等は容 易に解析的淂られる。

\section{3 一定高度，一定高度变化率飛行 (constant} altitude or constant altitude rate flight) $こ れ$ は高度変化率 $(\dot{h})$ を一定に保って降下する場合で，こ の特別な場合が一定高度飛行 $(\dot{h}=0)$ である：初期飛 行径路角 $\left(\gamma_{\mathrm{i}}\right)$ 少非常に大きくて空力荷重や空力加熱率 が制限值を超えることが予想される場合には，これら の飛行に移行し，飛行中に空気力に上ってエネルギー を消散させた後降下する方法がとられる．第6四は高 度 $120 \mathrm{~km}$ より一定知勢 (LEES の解析解) で大気圈に 笑入した後，高度変化率 $(\dot{h})$ が0となったところで一 定高度飛行江移行した例を示す。

\section{5. 空気力と制御変数}

回収体に加わる空気力（揚力，抗力）は第 7 図のよ

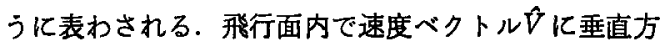
向を $\hat{l}$, 飛行面任直角方向を $n$ とすれば揚力 $L$ に上る 加速度 $(L / W)$ は次式で表わされる.

$$
\frac{L}{W}=\frac{C_{\mathrm{D}} A}{2 W} \rho V^{2}\left(\frac{L}{D}\right)(\hat{l} \cdot \cos \beta-\hat{n} \cdot \sin \beta)
$$

いま揚力 $L を$ 変化させて，軌道をコントロールするあ のとし, 弾道係数 $\left(W / C_{\mathrm{D}} A\right)$ が一定と仮定すれば，制 御変数は揚抗比 $(L / D)$ またはバンク角 $(\beta)$ である. 揚抗比 $(L / D)$ は回収体の形状が，ジェニやアポロ のような軸対称型，いわゆるカプセル型の場合，ほと んど一定であり，このときはバンク角 $(\beta)$ のみの制御 ということになる. しかしこの場合には直角方向（A 方向）にも揚力の成分が発生するため，横方向（ク口 スレンシ）の軌道コントロールが必要となる.機体の 形状が非軸対称の揚力体（リフティングボディ）また はシャトル・オービターのような有翼型で，極超音速

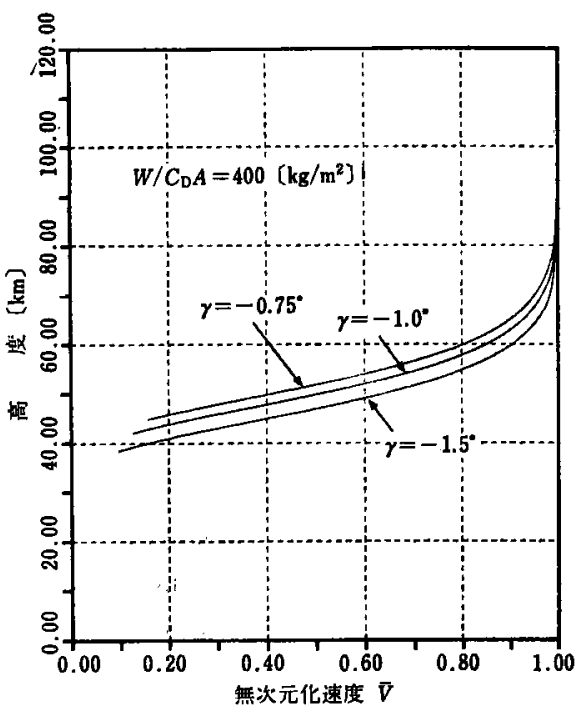

第 5 因 一定飛行経路角飛行

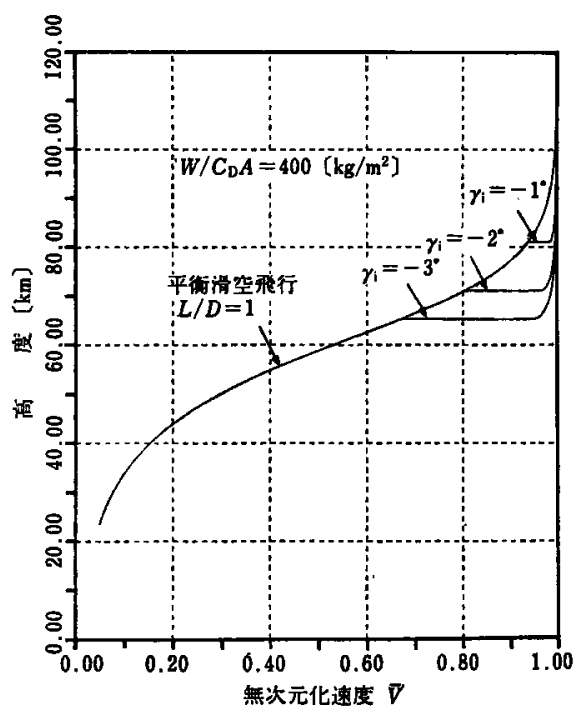

第6四一定高度飛行

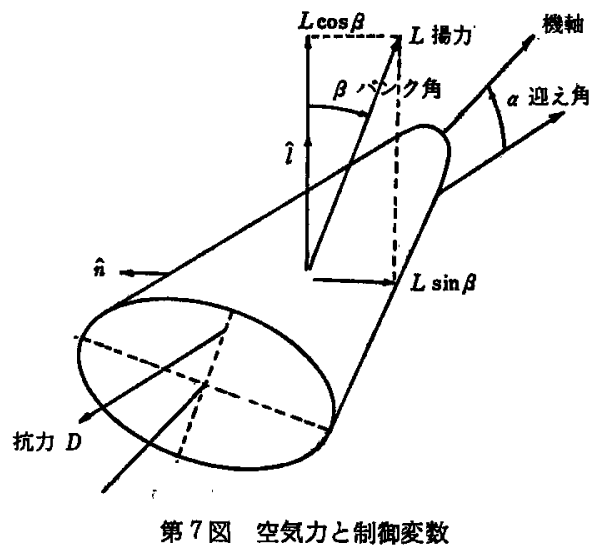


飛行 (マッハ数>5) を行う場合には, 二ュートン流近 似が用いられる.ニュートン流近作では揚力係数 $\left(C_{\mathrm{L}}\right)$, 抵抗係数 $\left(C_{\mathrm{D}}\right)$ は機軸と速度べクトルのなす角，すな わち迎え角 $(\alpha)$ の関数として次のように与えられる。

$C_{\mathrm{L}}=C_{\mathrm{LD}} \sin ^{2} \alpha \cos \alpha$

$D_{\mathrm{D}}=C_{\mathrm{DO}}+C_{\mathrm{DL}} \sin ^{3} \alpha$

$C_{\mathrm{LO}}, C_{\mathrm{DO}}, C_{\mathrm{DL}}$ はいずれあ機体形状によって决まる 定数である. このとき揚抗比 $\left(L / D=C_{\mathrm{L}} / C_{\mathrm{D}}\right)$ は

$L / D=C_{\mathrm{LO}} \sin ^{2} \alpha \cos \alpha /\left(C_{\mathrm{DO}}+C_{\mathrm{DL}} \sin ^{3} \alpha\right)$

で与えられ，迎角 $(\alpha)$ のの関数となる。

したがって揚力体, 有翼型の回収体の場合は制御变 数は迎え角 $(\alpha)$ またはバンク角 $(\beta)$ である.

以上から回収体のおすな制御対象である飛行距離 (ダウンレンジ)と制御変数の関係は次のように表わさ れる(第 9 図).

\section{6. 回収体の影管方式の分類とその例}

回収体の誘導は第 1 表のように分類される. 大別す るとインプリシット法とイクスプリシット法がある. インプリシット法は飛行前に基準の軌道を決めてお く.もし軌道がこの基準軌道からずれると基準軌道に 治うように誘基を行うすので, 目標の着地点もあらか しめ基準軌道で決められた点である．この誘徆法の特
徽は飛行中の誘導計算がきわめて簡単で，四則演算で すむことである．しかし基準軌道のデータを大量に記 憶しておかなければならず，また飛行途中で目標点地 域の気象条件等によって着地点を変えたいとしてもい ったん大気圈に突入した後はその変更は不可能であ る. このため一般に柔軟性に欠けるといわれている.

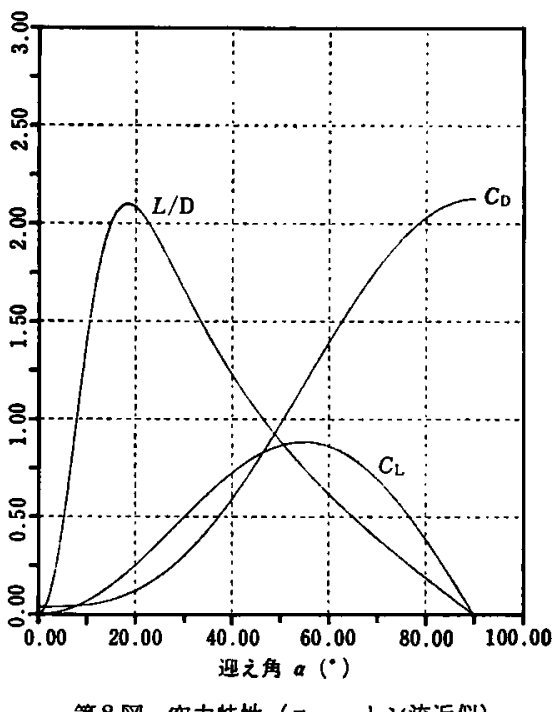

第 8 园空力特性（二ュートン流近做）

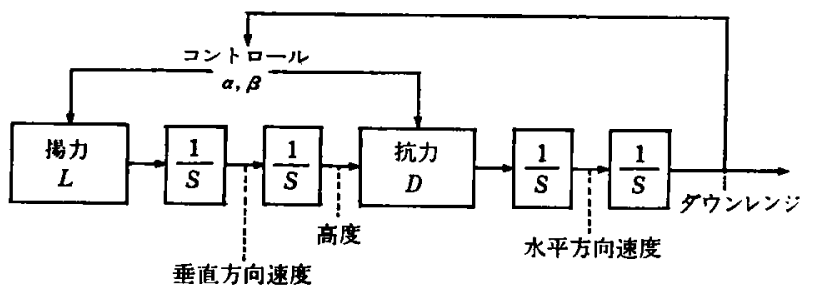

第 9 因 軌道パラメータと制御変数

$\frac{1}{S}:$ 䞍分記号, $\alpha, \beta$ : 迎え角, メンク角

第 1 表 回収体の褋導方式の分類

\begin{tabular}{|c|c|c|}
\hline 誘 & 式 & 概 \\
\hline \multirow[b]{2}{*}{ インプリジ } & $\begin{array}{l}\text { 固定ゲイン砶 } \\
\text { 隹法 }\end{array}$ & $\begin{array}{l}\text { 基隼仇道の轨道バラメータ（レンシ，高度，抗力等）と実䑤行洔の軌道パラメー } \\
\text { タとの差に一定ゲインをかけてコントロール変数 }(\alpha, \beta) \text { を計算する. }\end{array}$ \\
\hline & $\begin{array}{l}\text { 可変ゲイン誘 } \\
\text { 望法 }\end{array}$ & $\begin{array}{l}\text { 基準軌道の軌道パラメータと実飛行洔の軌道パラメータとの差に可変ゲインをか } \\
\text { けてコントロール変数を計算する. ゲインは運動方程式を基準軌道のまわりて線形 } \\
\text { 化しこの線形改分方程式を解くととによって得られる. 得られだゲインは速度また } \\
\text { は時間の関数として記滰される. }\end{array}$ \\
\hline \multirow{2}{*}{$\begin{array}{l}\text { イクスプリシ } \\
\text { ット影集方式 }\end{array}$} & $\begin{array}{l}\text { リアルタイム } \\
\text { 予測程分法 }\end{array}$ & 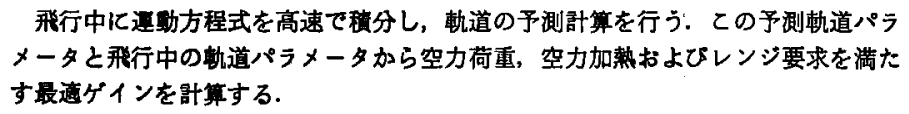 \\
\hline & 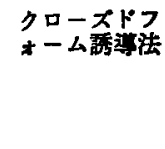 & 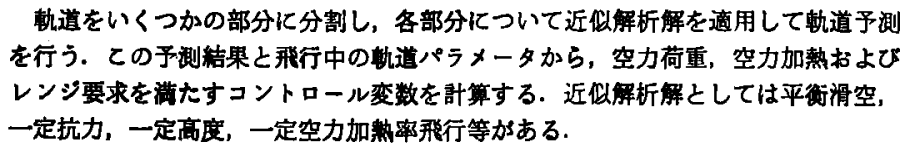 \\
\hline
\end{tabular}


イクスプリシット法は基準軌道は必要とせず，目標 点之回収体の飛行状態との関㐿のみによって誘導指令 (迎え角, バンク角) を出す. との誘導法は基準軌道を 必要としないかわりに目標点までの軌道の予測計算が 必要之なる.つまり回収体の各時点における飛行状態 (高度，速度，動圧，加熱率等）で地表までの飛行を予 测したとき，目標点からのずれを計算し，てれを修正 する. さらにこの飛行中に空力荷重制限, 空力加熱制 限を超えるととが予測される場合にはとれをさける誘 導指令が出される. この方法を実行するには，回収体 の運動方程式，および空力荷重または空力加熱に関す る評価関数を高速に解く必要がある。これはりアルタ

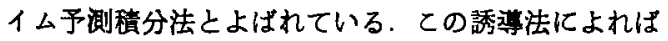
回収体を飛行状況に応じた最道の誘導ができ，また飛 行途中で目標点（着地点）の変更も可能である．乙れ をインプリシット法と比へると搭載計算機に対する演 算機能要求は，はるか儌しく現在の技術レベルでは 実現されていない，しかし，将来は搭载計算機の急速 な性能向上に伴ってての誘導方式へ移行するものと思 われる. このように回収体の運動方程式を高速で積分 して轨道予湘を行うことがむずかしいととから，予測 軌道として運動方程式の近似解析解を用いる方法が採 られる.てれをクローズドフォーム誘導と称している. 近似解析解としては(4)節で述へた種々の解析結果が 用いられる. この誘導法はシャトル・オービターの回 収誘導に用いられており，誘導計算の簡便さ，柔㳄性 からいって現在の回収体誘導法の主流である.

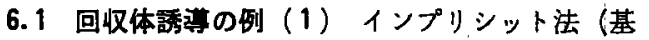
準軌道を用いた誘導) の最も簡単な例として，一定バ ンク角誘覚について示す (第 10 困). 機体はカプセル
型を想定し揚抗比（ $L / D=0.2 ）$ は一定とする.そし て軌道のコントロールはパンク角 $(\beta)$ のみで行う．こ の回収体の基準軌道は, 高度 $80 \mathrm{~km}$, 飛行径路角 $-2^{\circ}$ を初期值とし，一定姿劸 $\left(\beta=45^{\circ}\right)$ で飛行するものと すれば，终端点は $A$ 点となる．乙の点を目標点として， 初期飛行径路角に一 $-0.2^{\circ}$ の愦差を与え，誘導を行わ ず一定姿勢 $\left(\beta=45^{\circ}\right)$ のまま飛行すれば B 点任到達す る. 目標のA点との距離誤差は約 $91 \mathrm{~km}$ である、い ま，飛行中の速度 $(V)$ 之飛行距離 $(X)$ の計測加行わ 机，基準軌道の飛行距離 $\left(X_{\text {nom }}\right)$ 加速度 $(V)$ の関数之 して記憶されているるのとする. 飛行距離の誤差 $\Delta X$ $\left(=X-X_{\mathrm{nom}}\right)$ 加許容值 $\pm \Delta X_{\mathrm{L}}$ を超えた場合には，次 の上うにバンク角 $(\beta)$ を変化させる.

$\Delta X \geqq \Delta X_{\mathrm{L}}, \beta=90^{\circ}$ (またはスピン): 弾道飛行 $\Delta X<-\Delta X_{\mathrm{L}}, \beta=0^{\circ} \cdot$ 最大揚力飛行

との論理を付加して上記と同じ初期飛行径路角誤差 $-0.2^{\circ}$ を与えた場合, 到達点はC 点となり, 目標点 A点との距離譟差は約 $16 \mathrm{~km}$ である。このような简単 な誘導でも無誘導に比へて誘導の効果が表われており 米国のシェミニ・カプセルの回収 (1964 1966) 飞採 用された。

6.2 回収体誘恶の例 (2) 同じくインプリシット 法で基旿軌道と固定ゲインを用いた誘票の例を示す (第 11 図)．この誘導法はカプセル型または揚力体(リ フティングボディ）に墖用されている例が多い，回収 体の揚抗比の基準値 $(L / D)_{\text {nom }}$ を 0.4 とする. この揚 抗比をあつ回収体加，高度 $80 \mathrm{~km}$ ，飛行径路角 $-2^{\circ}$ を 初期值として飛行した軌道を基準軌道とする．との軌 道の到達点はA点である.

いま，回収体が初期飛行径路角誤差 $-0.4^{\circ}$ で，揭抗

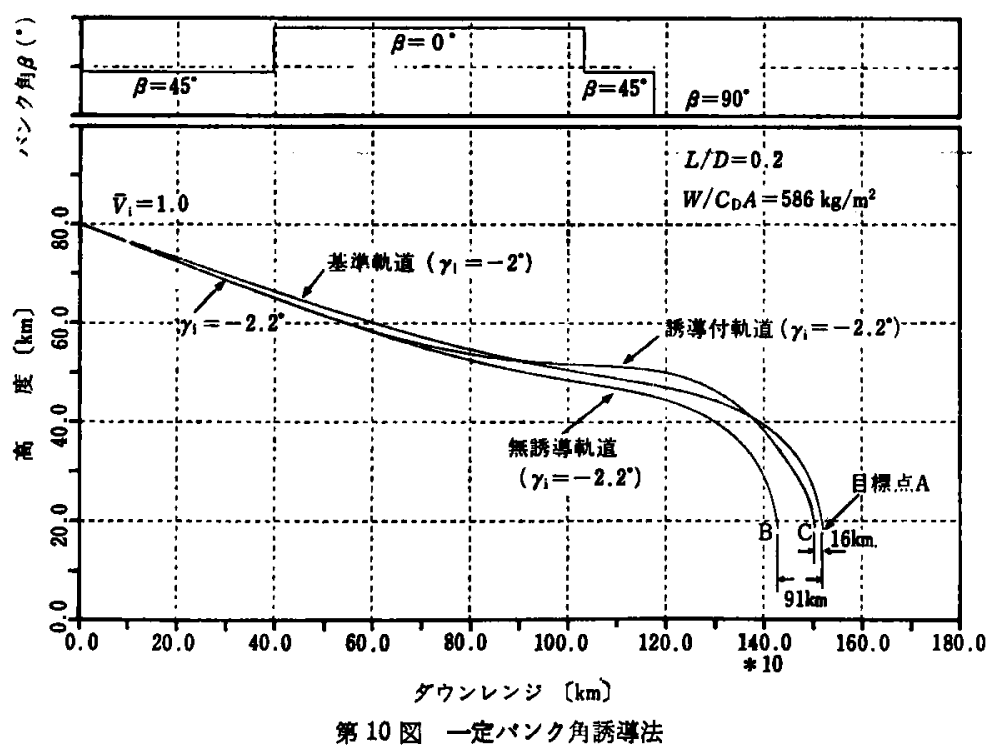

(682) 


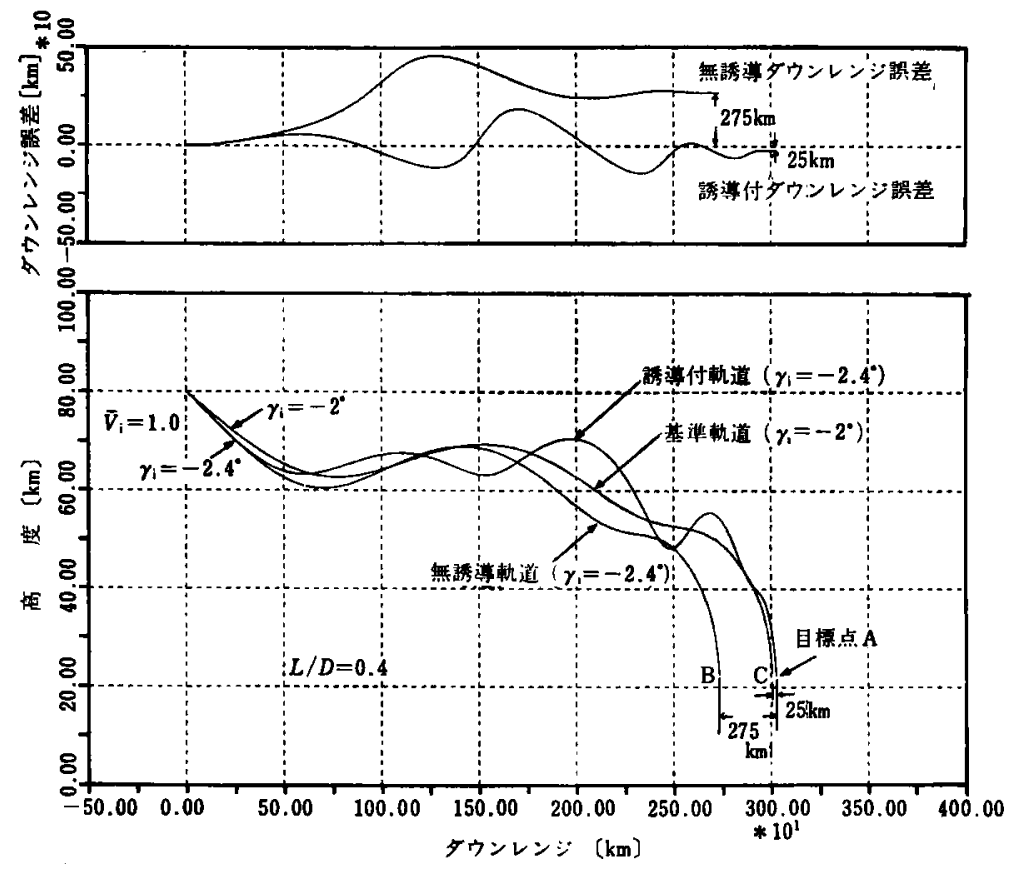

第11 图 固定ゲイン箱登法

比は基準值のまま無誘尊で飛行したとすれば $\mathrm{B}$ 点に到 達し，目標の A 点との距離誤差は約 $275 \mathrm{~km}$ である.

次に基準軌道の水平方向の速度 $u_{\text {nom, }}$ 高度 $h_{\text {nom }}$ 抽 よび飛行距離 $X_{\text {nom }}$ が速度 $(V)$ の関数として記憶され ているすのとする，飛行中に計测された速度 $(\boldsymbol{u})$, 高 度 $(h)$ ，飛行距離 $(X)$ か力基準值に比べて愦差があれば ゲイン $\left(K_{1} \sim K_{3}\right)$ を加りて，次式で揚抗比 $(L / D)_{\text {som }}$ を修正する。

$$
\begin{aligned}
L / D= & (L / D)_{\mathrm{nom}}+K_{1}\left(u-u_{\mathrm{nom}}\right)+K_{2}\left(h-h_{\mathrm{nom}}\right) \\
& +K_{3}\left(X-X_{\text {nom }}\right)
\end{aligned}
$$

ここでゲイン $\left(K_{1} \sim K_{8}\right)$ は次の值に纳設定する.

$$
\begin{aligned}
& K_{1}=-4.15 \times 10^{-4}(\mathrm{sec} / \mathrm{m}) \\
& K_{2}=-9.84 \times 10^{-5}(1 / \mathrm{m}) \\
& K_{3}=-3.28 \times 10^{-0}(1 / \mathrm{m})
\end{aligned}
$$

との方法で上記と同じ初期飛行径路角祸差 $-0.4^{\circ}$ を与え䚽造を行ったとき，到達点はC 点となり誘導の 効果加表われている.

制御システムはこの揚抗比 $(L / D)$ を迎え角 $(\alpha)$ ま たはハンク角 $(\beta)$ 湾換して送られる.ここで用いた ゲイン $\left(K_{1} \sim K_{3}\right)$ はこてでは仮に設定したもので，乙 の誘蓫法を用いる場合には，基䇢軌道が設計された段 階で最る通当なるのが選定される。

6.3 回収体看盗の国（3）次にインプリシット法 のうち，可変ゲインを用いた誘学法の例を述へる。 と の方法は回収体の軌道パラメータ，たとえば飛行径路 角 $(r)$ ，抗力 $(D)$, 飛行距離 $(X)$ 加基準軌道加らあ

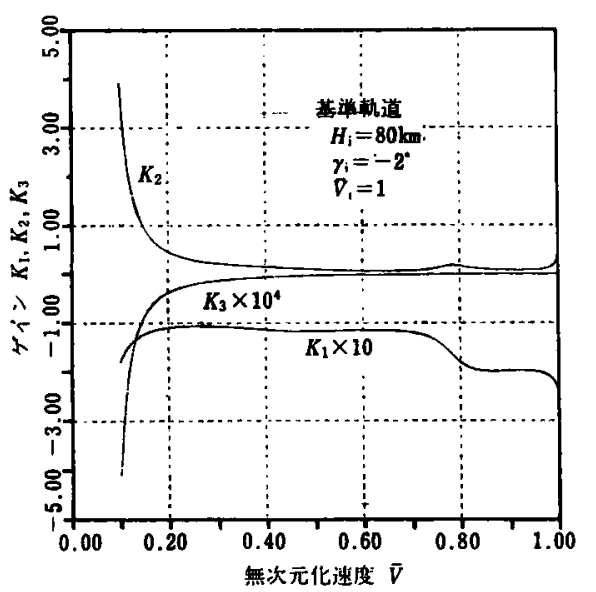

第12四可変 ゲイン

まりずれないと扳定して，回収体の運動方程式を線形 化する. ての線形化された連立微分方程式に対して随 伴方程式を解くことにより大気圈哭入時から地表に到 達するまでの軌道に洛ったゲイン $\left(K_{1} \sim K_{3}\right)$ が計算で きる．第12図にその計算例を示す．とのゲインを使用 して，基準軌道汇おけるパンク角 $(\cos \beta)_{\mathrm{nom}}$ を軌道の ずれに応じて修正する。

$$
\begin{aligned}
\cos \beta= & (\cos \beta)_{\mathrm{nom}}+K_{1}(V)\left(\gamma-\gamma_{\mathrm{nom}}\right) \\
& +K_{2}(V)\left(D-D_{\mathrm{nom}}\right)+K_{3}(V)\left(X-X_{\mathrm{nom}}\right)
\end{aligned}
$$

この方法で誘導を行って初期飛行径路角㜔差 $+0.8^{\circ}$ を修正した結果を第13図に示す，無誘導時の到達点 B 


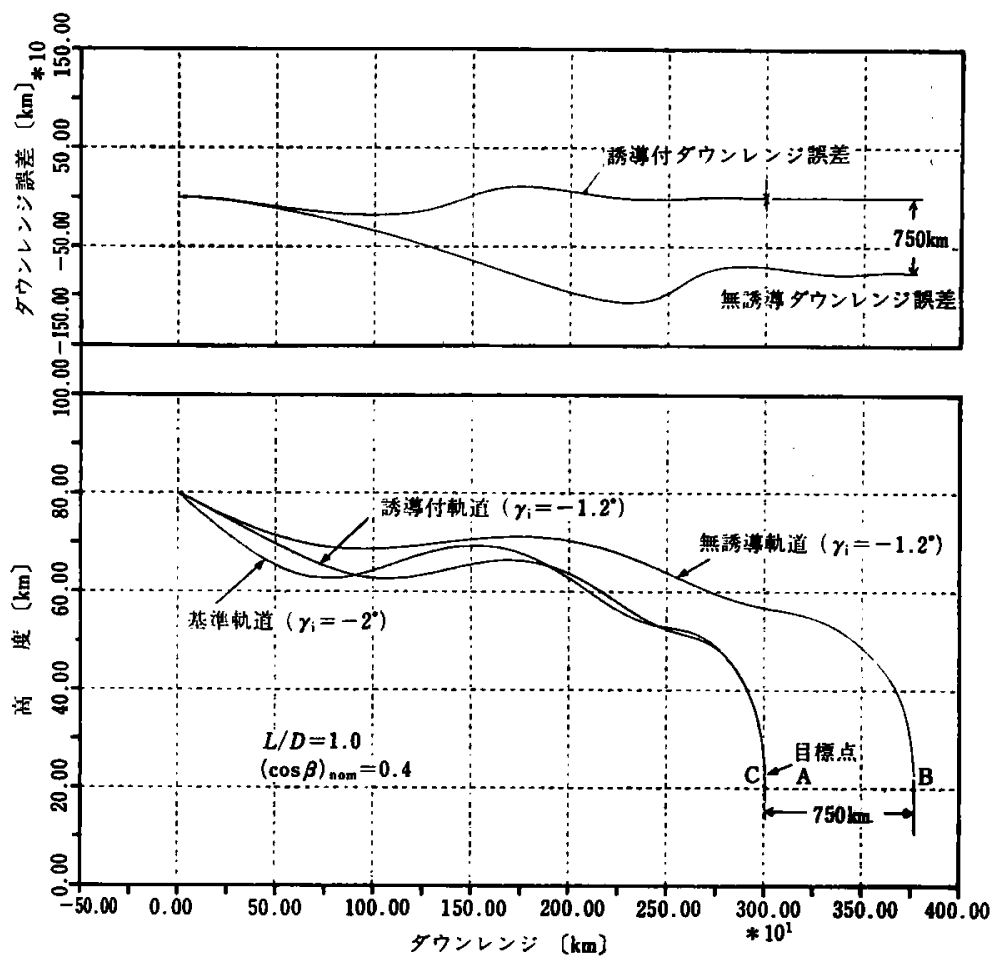

第 13 図 可変ゲイン誘望法

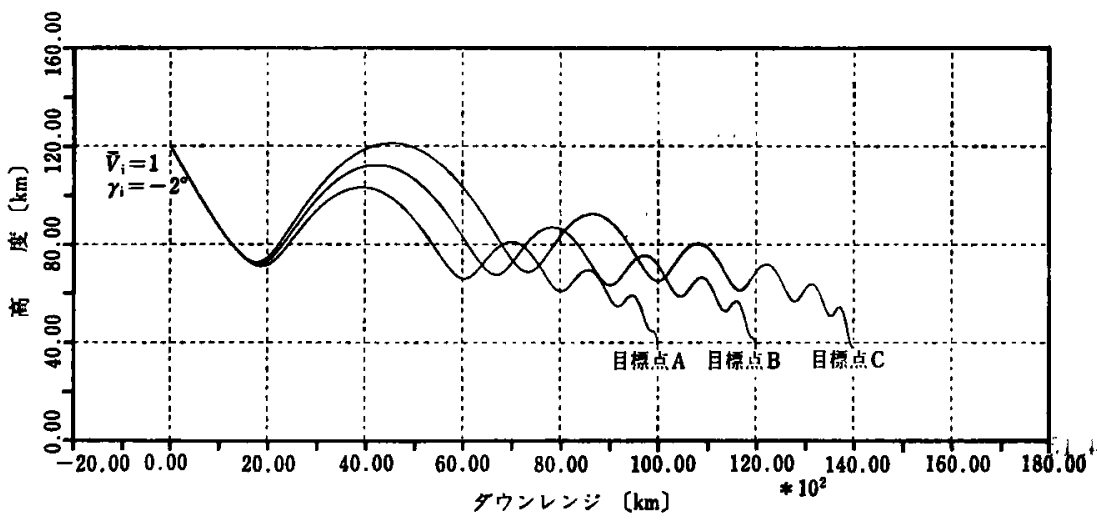

第 14 因クローズドフォーム誘学法（軌道予剧：平衡滑空飛行）

は目標点Aに対して約 $750 \mathrm{~km}$ の誤差をるつがてれか 誘導により修正されていることがかかる．また軌道の 制御はこてに示したようにバンク角 $(\beta)$ によらず，迎 え角 $(\alpha)$ によっても可能である. との誘導法を使用す る場合にも基準軌道の軌道パラメータと,ゲイン( $K_{1}$ $\left.K_{3}\right)$ が速度 $(V)$ の関数として記憶されていなりればな らない，文献”ではミッション軌道を離脱して大気圈 上限（高度約 $120 \mathrm{~km}$ ) に䢖するまでの間にこの基準軌 道とゲインの計算を行うことを提案している．との場 合，搭載計算機の記憶容量は少なくてすみ，ミッショ ン柔軟性は增すか，計算時間が問題となる．本文城で
は高度 $180 \mathrm{~km}$ の円周軌道加ら大気圈上限化運するま での時間は約 208 秒, 高度 $1,800 \mathrm{~km}$ からは約 1,504 秒 程度あり，十分に計算の余裕があるとしている.

6.4 回収体䛴基の例（4）イクスプリシット法の 代表的な例としてクローズドフォーム誘導法を用いた 高揚力回収体 $(L / D=2 \sim 3)$ の計算例を示す. いま平 衡滑空飛行軌道を予测軌道として用いるととにすると 目標点までの飛行距離 $\left(X_{f}-X\right)$ と要求㧹抗比 $(L / D)$ c の関係は次のように与えられる.

$$
\left(\frac{L}{D} \cdot \cos \beta\right)_{\mathrm{e}}=\frac{2\left(X_{\mathrm{f}}-X\right) / \mathrm{ro}_{0}}{\ln \left\{\left(1-\bar{V}_{\mathrm{f}}^{2}\right) /\left(1-\bar{V}^{2}\right)\right\}}
$$


ここで， $X_{1}$ は目標点の距離(定数)，roは地球半径， $\bar{V}$ は地球周回速度 $V$ oro で無次元化した速度， $\bar{V}_{\mathrm{f}}$ は 目標点における速度（定数）である. 飛行中の回収体 の速度 $(\bar{V})$ と飛行距離 $(X)$ 加計測されているあの之 すれば，目標点との関係のみで要求揚抗比が計算でき る. 第14図は高度 $120 \mathrm{~km}$ 上り初期飛行径路角 $-2^{\circ}$ て 大気圈に突入し，それぞれの目標点に向かって飛行し たものである、また第 15 図は約 $5,000 \mathrm{~km}$ を飛行した ところで，最初の目標点を約 $2,000 \mathrm{~km}$ 延長し新しい 目標点に向かって飛行した場合である。このようにク ローズドフォーム誘通では目標点が与えられればよ く，その過程で基準軌道は必要としない，しかもこの
例のように飛行中に目標点の変更があってあ十分対応 が可能である．第16四はこの誘導法を用いて種々の初 期飛行条件（この例は初期飛行径路角を变えたすのて

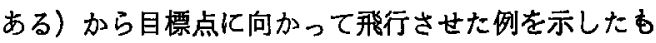
のでおる，なおての例では第14図，第15図の phugoid 振動をおさえ，滑らかに誘導を行ったものである．

同様の誘導は他の近似解析解を予測軌道として用い ても可能で, 第17図は一定抗力飛行軌道を用いて目標 点まで誘導した例である．実際にこのクローズドフォ 一ム誘導を用いる場合には以上の例のように大気圈上 限から地表まで一つの近似解析解を用いることは少な く，回収体の飛行状態に応じて幾つかのフェーズにわ

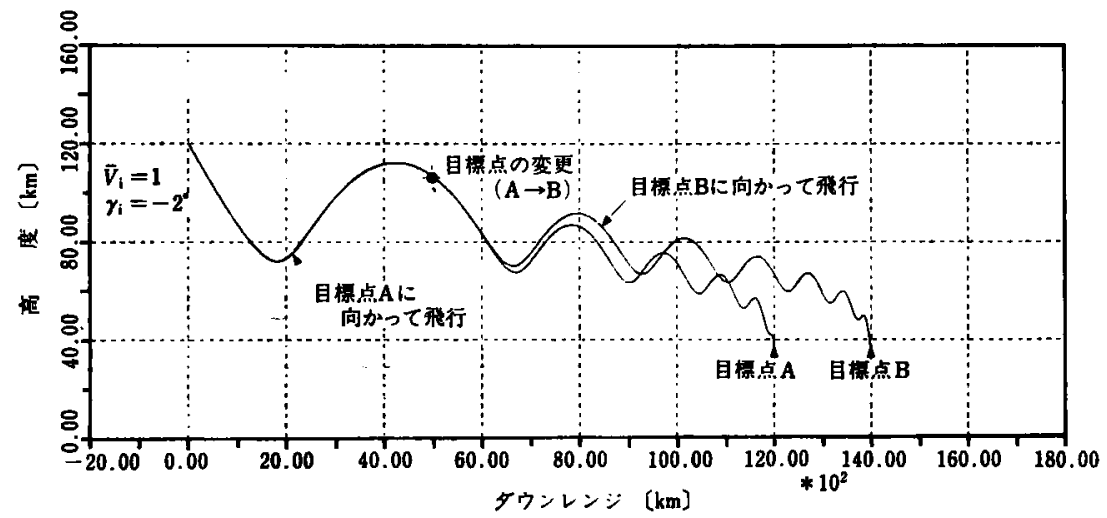

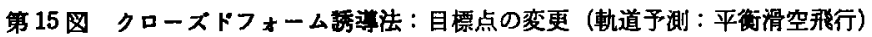

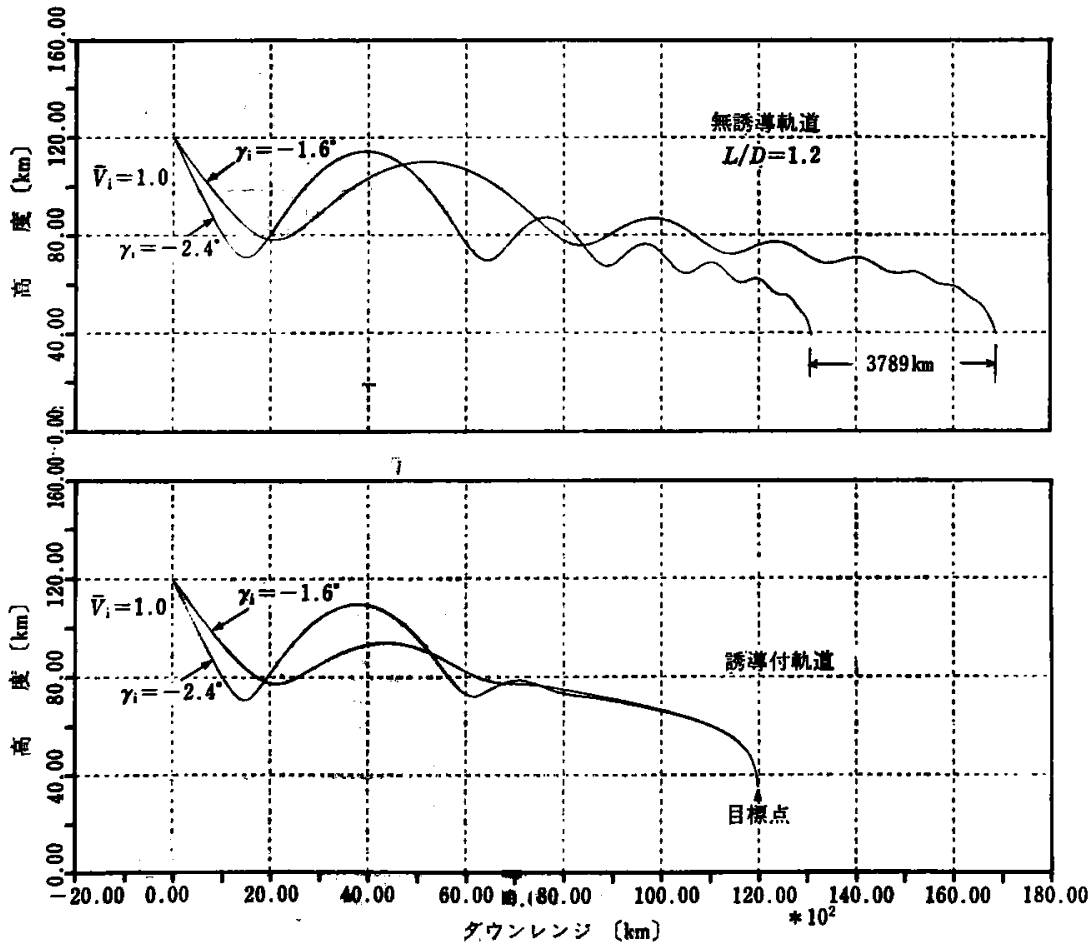

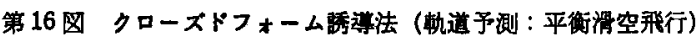


第 347 号（1982年 12 月）

け，それそれ適当な近似解を用いる．この典型的な例

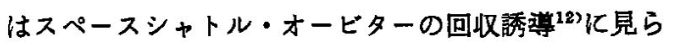
れ, 空力加熱制御, 平衡滑空飛行, 一定抗力飛行 一ズ等にわけられている.

以上の例からわかるようにクローズドフォーム誘導 はインプリシット法に比へて演算の簡単さには多少欠 けるが，大量の記憶容量は必要としないとと，制御可 能な範囲内で，どのような飛行状態からでも目標点に 向かうことができ，しかも飛行中に目標点の変更が可
能であるとと，等からミッション柔軟性が大きいとい われている.

6.5 回収体敦導の例（5）最役にイクスプリシッ ト法の例としてリアルタイム予測啨分法について迹へ 了. 回収体加降下中に運動方程式を高速で積分し，先 の軌道予测を行うことは現状ではむすがしいけれども 3 章で述へた CHAPMAN の微分方程式 ( $\boldsymbol{Z}$ 関数の水平 速度 $u に$ 関する 2 階の微分方程式）等を用いるととに より近似的に，高速で程分し，軌道の予湘を行うこと

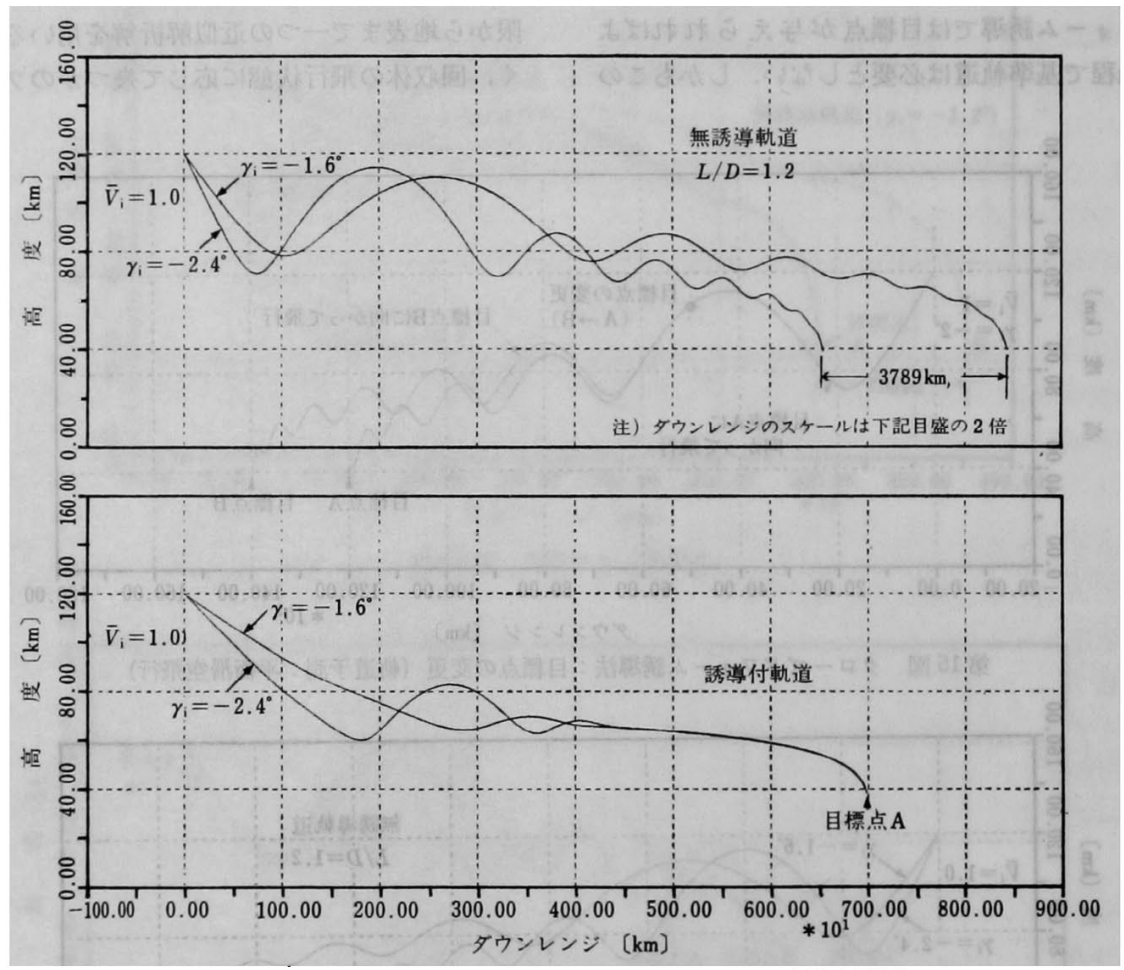

第 17 图クローズドフォーム誘導法（軌道予测：一定抗力飛行）

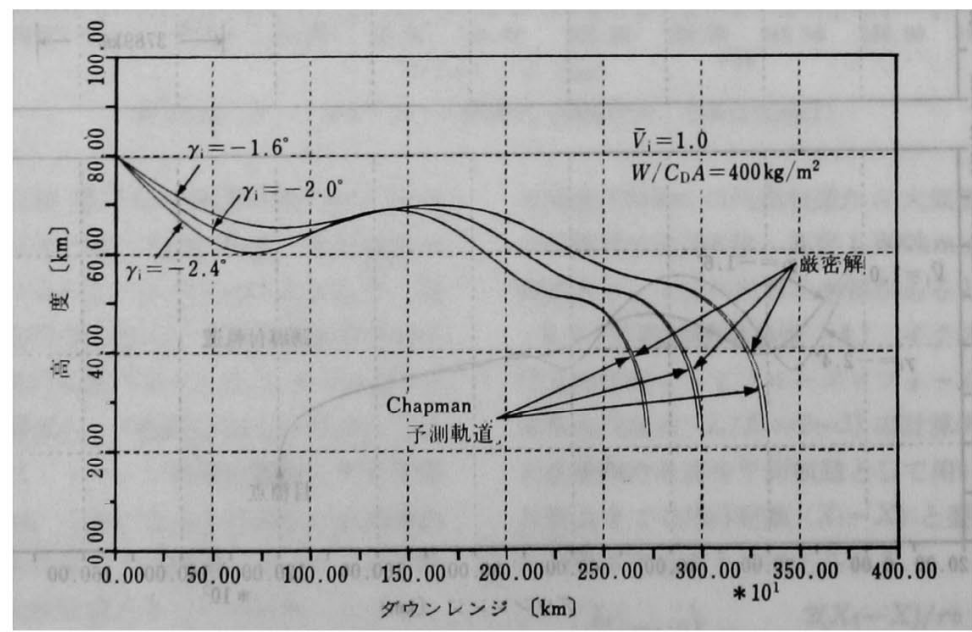

第18四 CHAPMANN の微分方程式による軌道予測 
ができる、ここでは空力加熱率，加熱量，抗力加速度 等に関する拘束や最道性についてはふれず，CHAPMAN の微分方程式による轨道予测能力について示す. 第18 困はこの微分方程式を台形皘分公式を用いて皘分し， 予测軌道を計算したものである．との四からわかるよ うに，非常によく铱密解と一等するが，軌道の後端で わずかにずれてくる．これは CHAPMAN の微分方程式 の算出の仮定が $(L / D) \cdot \tan \gamma \ll 1$ であるためで軌道の 後端では飛行径路角 $(\gamma)$ が大きくなり，との仮定から はずれてくるからである.この軌道予测法は掦抗比 $(L / D)$ が大きい場合にも適用できるがての場合，上 記の仮定から，我行径路角 $(r)$ が小さい䇭囲汇限られ る. 以上のように CHAPMAN の微分方程式による轨道 予測法は非常に精度がよいので，一つの応用として， インプリシット法で基準軌道の代りに使用すれば，基 準軌道の軦道パラメータを記憶する必要はなくなり， その久点の一つが改善できる。

\section{7.あとがき}

回収体の軌道の特徽之誘導方式の分類, およびその 例を紹介したが，簡単のために飛行面内（2次元）で の考察を主とした．本稿は航空宇宙技術研究所との共 同研究「回収体誘導制御システムの研究」でスタディ した内容の一部をまとめたものである.われ㧈はク ロスレンシの軌道コントロールを含めた 3 次元での種 種の回収体の誘導について解析を進めており機会があ 机ば紹介したい。

おわりにで支援をいただいた航空宇丒技術研究所， 山中, 新田, 森, 各主任研究官に感謝の意を表した い.

\section{若文载}

1）森英彦，新田虔治，山中能夫：シェミニ型カプセル 回収体の概念榆討一生物衙星への们用一. NAL TM436 (1981.5).

2) 柴藤羊二，伊藤哲一：小型有琪機の概念研究，第24回 宇宙科学技術連合亚演会 (1980.10).

3）森 英彦：ジェミ二型飛しょう体の回収における机道 とダイナミックス, NAL TR-651 (1981.1).

4) Allen, H.J. and Eggers, A. J. : A Study of the Motion and Aerodynamic Heating of Missiles Entering the Earth's Atmosphere at High Super Sonic Speed, NACA TN 4047 (1957. 10).

5) Lees, L., Hastwing, F. W. and Cohen, C. B. : Use of Aerodynamic Lift During Entry into the Earth's Atmosphere, ARS Journal (1959.9).

6) Arthur, P.D. and Karrenberg, H.K. : Atmospheric Entry with Small $L / D$, Journal of the Aerospace Sciences, Vol. 28, No. 4, (1961.4), pp. 351-352) .

7) Eggers, A. J., Allen, H. J. and Neice, S. E. . A Comparative Analysis of the Performance of Long-Range Hypervelocity Vehicles, NACA TN 4046 (1957. 10).

8) Chapman, D. R. . An Approximate Analytical Method for Studying Entry into Pranetary Atmosphere, NASA TR-R-11 (1959).

9) Perlmutter, L. D. and Carter, J.P.: Refference Trajectory Re-Entry Guidance without PreLaunch Data Storage, AIAA Paper, No. 65-48 (1965, 1), pp. 1-16.

10) Wingrove, R.C.: Survey of Atmosphere Re-Entry Guidance and Control Method, AIAA Journal, Vol. 1, No. 9 (1963.9), pp. 2019-2029.

11) Tannas, L. E. and Perkins, T.R.: Simulation Evaluation of Closed Form Reentry Guidance, AIAA Paper, No. 67-597 (1967.8.), pp. 1-9.

12) Harpold, J.C. and Graves, Jr. C. A. : Shuttle Entry Guidance AAS 78-147 (1979).

13) Metzler, R. A. and Powers, W. F. : Optimization Techniques Applied to Space Shuttle Explicit Re-Entry Guidance Law Design; Journal of the Astronautical Science, Vol. XXVI, No. 1 (1978. 1 3), pp. 47-68.

14) Loн, W. H. : Re-Entry and Pranetary Entry Physics and Technology, Applied Physics and Engineering/An International Series (1968). 